\title{
Assessing Tree Species Dominance along an Agro Ecological Gradient in the Mau Forest Complex, Kenya
}

\author{
Mwangi James Kinyanjui ${ }^{1}$, Chris A. Shisanya ${ }^{2}$, Ondimu Ken Nyabuti ${ }^{3}$, \\ Wargute Patrick Waqo', Merceline Awuor 0jwala1 \\ ${ }^{1}$ Department of Resource Surveys and Remote Sensing, Nairobi, Kenya \\ ${ }^{2}$ Department of Geography, Kenyatta University, Nairobi, Kenya \\ ${ }^{3}$ Department of Geography, Egerton University, Njoro, Kenya \\ Email: mwangikinyanjui@gmail.com
}

Received 7 August 2014; revised 9 August 2014; accepted 13 August 2014

Copyright (C) 2014 by authors and Scientific Research Publishing Inc.

This work is licensed under the Creative Commons Attribution International License (CC BY). http://creativecommons.org/licenses/by/4.0/

(c) (i) Open Access

\section{Abstract}

Species relative dominance by basal area was assessed along an agro ecological gradient in the Mau Forest Complex (MFC). Trees were recorded per species and diameter at breast height $\left(D_{1.3}\right)$ for size class $D_{1.3} \geq 10 \mathrm{~cm}$ in 60 quarter hectare plots distributed in 7 agro ecological zones (AEZ) namely LH1, LH2, LH3, LH4, UHO, UH1 and UH2. Basal area per species was used to calculate species relative dominance i.e. the proportion of basal area by a species to the total basal area of the AEZ. Species associations were analysed as the group of highly ranked species in each AEZ. Sorensons similarity index was used to calculate the proportion of similar species among AEZ. Analysis of variance compared basal area among AEZ and Tukey's multiple comparison test used to identify specific AEZ with differences. Tabernaemontana stapfiana (Britten) was ranked first in LH1, UH1 and UHO with relative dominance values of $22.66 \%, 22.89 \%$ and $30.73 \%$ respectively. It was however not recorded in any other AEZs. Dombeya goetzenii (K. Schum) occurred in 6 of the 7 AEZs but had moderate dominance values in each of the 6 AEZs. The sum of dominance values per species in all AEZs indicated no species mono-dominance and different species dominated at different AEZs. Co-dominance resulted in species associations like Tabernaemontana-Allophylus-Ekebergia-Albizia in LH1, Juniperus-Dombeya-Casearia-Prunus in LH2, Acokanthera-Cussonia-OleaTeclea in LH4 and Tabernaemontana-Syzygium-Podocarpus-Neoboutonia in UH1. Species richness was highest in UH1 and had the highest similarity indices with those of other AEZs. The UH1 had a species similarity of $67 \%$ with LH1, $63 \%$ with LH2 and $56 \%$ with LH4. However, species in the very humid zone UHO differed with those of the drier lower highland zones (UHO vs LH3 and vs LH4 = $31 \%$ and $37 \%$ respectively). Basal area differed significantly among AEZ $\left(\chi_{0.05,9}^{2}=3.76\right)$ showing that they differ in stocking levels. Tukeys test showed that high potential zones of LH1, LH2, UH0, 
UH1 did not differ and similarly the lower potential zones; LH3 and LH4. The results show that the variation of species and forest stocking in the MFC is strongly influenced by AEZ and proposes future biomass mapping to be done along AEZ.

\section{Keywords}

Species Dominance, Basal Area, Agro Ecological Zoning

\section{Introduction}

Dominance is an important indicator of species composition in a forest [1] [2]. The dominance of a species refers to its relative importance in its habitat [3], which determines the degree of influence of the species on the ecosystem [4]. In a forest, species dominance has been studied from the forest attributes of vertical and horizontal characteristics [5] [6]. The forest's vertical structure shows the differentiation of trees into height categories, which results into various canopies. Reference [2] and [7] noted that in a natural uneven aged forest, canopy differentiation often results in emergents, the top canopy, the middle canopy and the lower canopy, which in most cases, are species specific.

Reference [8] defined the analysis of a forest's horizontal structure as assigning individual trees into specific sizes. Reference [5] used the species Importance Values Index (IVI) to rank the dominance of tree species in a forest based on the horizontal forest structure. He evaluated species dominance in terms of basal area's contribution to the specific forest, the number of individuals of the species counted and the frequency of occurrence in the sample sites. Therefore [5] defined a dominant species as one that has big sized trees, many individuals and is spread out over the study area.

In a normal forest, there may be no single dominant species [9]. For example, [10] explained that species dominance is shared over more than 270 tree species in the Amazon with either of these species ranking slightly above the rest depending on the local ecological conditions. In conditions of no disturbance, [11] have shown that it is actually possible to predict the occurrence of a species in a habitat based on its ecological niche. Reference [12] defined "rough distribution areas" for species of trees, shrubs and lianas in Kenya although absence or over dominance of species in such areas can be associated with stress factors like fires and over extraction [9], which characterise sections of the Mau forest complex [13]-[15] [16].

\subsection{The Species of the Mau Forest Complex}

The Mau Forest Complex (MFC) is classified as a montane forest [17] due to altitude. It has moist and dry forest vegetation types in the windward and the leeward sides of Lake Victoria respectively [12]. The moist forests occurring at 2100 - $3300 \mathrm{~m}$ above sea level, with rainfall above $1500 \mathrm{~mm}$, have a richer species composition and are dominated by a variety of broad leaved species. These include Dombeya goetzenii (K. Schum), Tabernaemontana stapfiana (Britten), Dracaena afromontana (Mildbr), Hagenia abyssinica (Bruce J. F. Gmel), Nuxia congesta (Fresen), Croton macrostachyus (Delile) and Podocarpus latifolius (Thunb. Mirb).

The drier montane forests occurring at 1800 - $2900 \mathrm{~m}$ a.s.l. with annual rainfall of $700-1350 \mathrm{~mm}$ are characterised by species like Juniperus procera (Endl), Olea europaea ssp. africana (Mill. P. Green), Podocarpus falcatus (Mirb.), Cassipourea malosana (Baker. Alston), Acokanthera schimperi (A. DC. Schweinf), Ekebergia capensis (Sparrm.), Olinia rochetiana (A. Juss.), Teclea nobilis (Delile), Croton megalocarpus (Hutch) and Calodendrum capense (L. f. Thunb).

Reference [18] explained that species association is a strong characteristic of the vegetation of the MFC and co-dominance has resulted in forest formations such as Aningeria-Strombosia-Drypetes and Albizia-Neuboutonia-Polyscias. They however noted that due to human disturbance, the floristic characteristics of the forest have been compromised in some areas reducing the dominance of the commonly exploited species and favouring the non-commercial species. In addition, [13] noted that fire effects may have contributed to over dominance of the fire tolerant $T$. stapfiana and the pioneer species Neoboutonia macrocalyx (Pax) in some parts of the MFC. Reference [15] also explained that due to human disturbance, the regeneration potential of some species has been compromised and this affects their dominance. 


\subsection{Agro Ecological Zoning and Forest Biomass}

The Food and Agriculture Organisation (FAO) has categorised the world into Agro ecological zones (AEZ) [19]. Reference [20] explained that the categorization is based on climate, moisture availability, soil and landform, and land cover. In Kenya, [21] defined the characteristics of each AEZ based on moisture availability, temperature, length of growing period and suitability for various crops. Though the AEZ system was designed for crops so that farmers can be advised on probabilities of yields and risks, [22] explained it as a land resource mapping tool that gives the range of potential use of the land and associated constraints for better management. In forests, though site indices are more commonly used as indicators of productivity [23], differences in AEZ are expected to result in differences in species composition and also forest yield.

In the Mau Forest Complex [16] and [24] explained that forest inventory has been done for purposes of biomass mapping and greenhouse gas inventory. Since tree biomass is estimated from allometric equations which are strongly influenced by the specific wood density, [25], a variation of tree species among AEZ would influence the biomass contents in such forests. If a forest is dominated by species of higher specific wood density, then the carbon content might be higher

This study was set to analyse tree species dominance by basal area among AEZ and find out species that are favoured by various ecological conditions in the MFC. This would show species dominance, species co-dominance and species associations among ecological regions of the MFC. Dominant species influence characteristics of the ecosystem including biodiversity [12] and also determine the kind of allometric equations for biomass mapping and carbon estimation in the forest [16].

\section{Methods}

\subsection{Measurement of Tree Basal Area}

Data from several forest inventories was compiled for tree dominance analysis. The inventories were done to analyse species composition in four blocks of the MFC namely Southwest Mau, Transmara, Western Mau and Mt Londiani. The four blocks comprise 171,000 ha of the 400,000 ha Mau Forest Complex. They cover the range of altitude of the MFC with $2000 \mathrm{~m}$ above sea level as the lowest point in south western Mau block and $3000 \mathrm{~m}$ above sea level as the highest point in Mt Londiani block.

To avoid degraded sample points where mono-dominance may characterize species composition [9], plots were sorted from the inventory data and only those with 5 or more tree species in the diameter at breast height (presented here as $\mathrm{D}_{1.3}=$ tree diameter recorded at $1.3 \mathrm{~m}$ above the ground) category of greater than $10 \mathrm{~cm}\left(\mathrm{D}_{1.3} \geq\right.$ $10 \mathrm{~cm})$ were selected. This criteria selected 60 plots comprising 50 circular plots of $28 \mathrm{~m}$ radius $(0.2464 \mathrm{ha})$ and 10 square plots of $50 \times 50 \mathrm{~m}(0.25 \mathrm{ha})$. In each of these plots parameters of interest were taken as tree species and $\mathrm{D}_{1.3}$.

Basal area per tree was calculated as the area of a circle whose diameter was measured at $\mathrm{D}_{1.3}$ [8]. The sum of species basal areas was used to calculate basal area at plot level. Ranking of species for dominance was done using their percentage basal area contribution to the plot.

\subsection{Forest Stratification}

On a digital map of the Mau forest Complex, showing the positions of the sampled plots, a shape file of the AEZ of Kenya based on [21] and [26] was overlaid. The plots were clipped into the various AEZ and distributed as shown in Table 1. The sum of species basal areas was done for each AEZ and the tree species ranked for dominance in per AEZ. Figure 1 shows the distribution of the AEZ in the Mau Forest complex and highlights the position of the sampled blocks.

\subsection{Data Analysis}

Species relative dominance calculated as a percentage of the contribution of a species to the forest basal area [5] was used to rank species for each AEZ and compare species dominance among AEZ. This also identified species with dominance in many ecological conditions. Using Sorenson's coefficient of similarity [27] the degree of similarity of the species growing in the different AEZs was analysed to verify if different tree species grow in the specific AEZs. Single factor analysis of variance with hypothesis $\mu_{1}=\mu_{2}=\mu_{3} \cdots \mu_{7}$ was done to compare basal area among the AEZ to test if forest stocking varies among AEZ. Tukey's multiple comparison test [28] 
M. J. Kinyanjui et al.

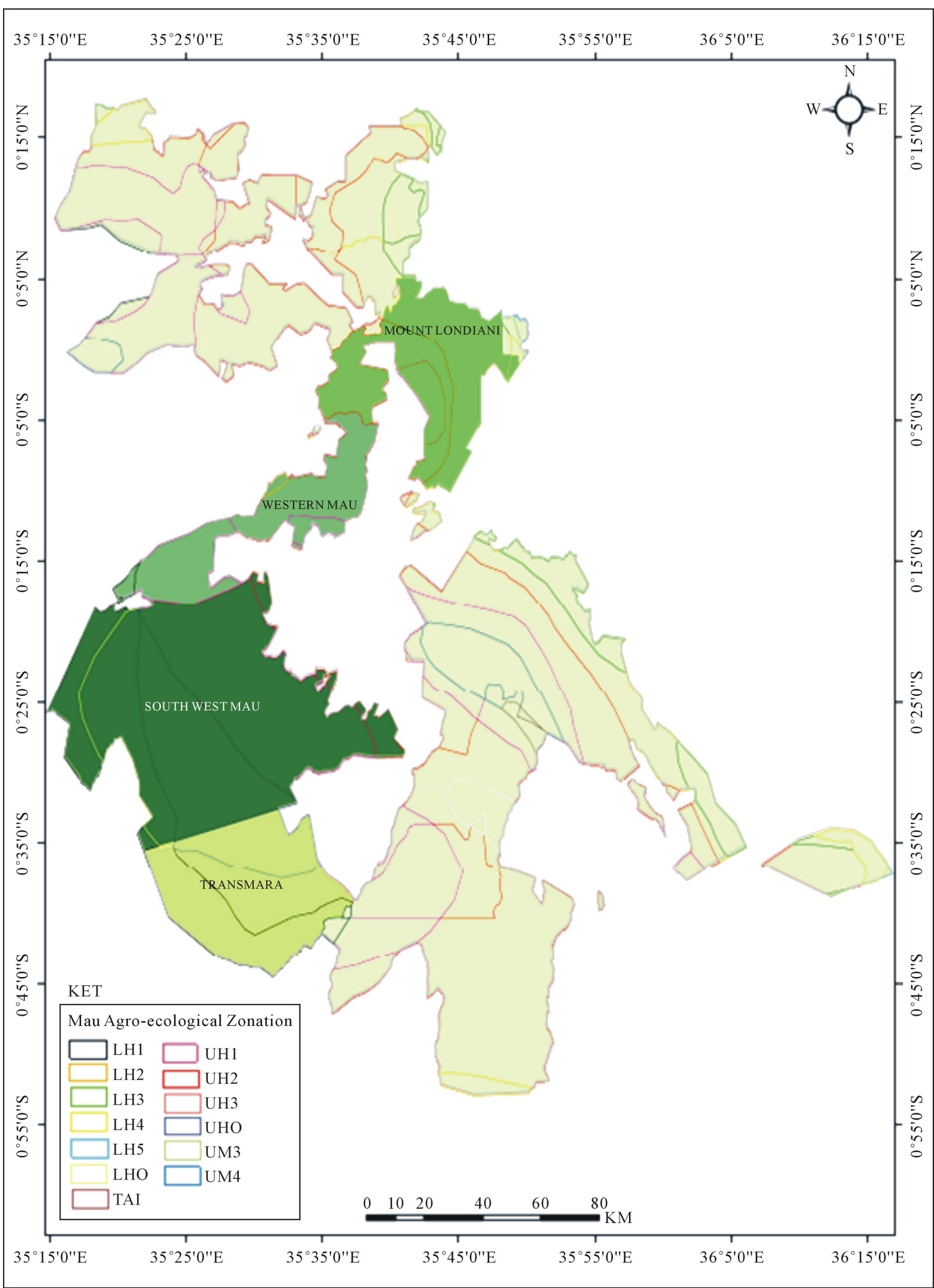

Figure 1. The sampled blocks of the MFC showing the agro ecological zonation. 
Table 1. Distribution of plots in the AEZ and their characteristics.

\begin{tabular}{|c|c|c|}
\hline AEZ & No. of plots & Characteristics of AEZ based on [26] \\
\hline LH1 & 10 & $\begin{array}{l}\text { Humid, Lower Highland. Length of growing period greater than } 270 \text { days. Evergreen, Annual mean } \\
\text { temperature } 15^{\circ} \mathrm{C}-18^{\circ} \mathrm{C} \text {, Monthly minimum } 8^{\circ} \mathrm{C}-11^{\circ} \mathrm{C} \text {, no frost }\end{array}$ \\
\hline LH2 & 6 & $\begin{array}{l}\text { Sub-humid, Lower Highland. Length of growing period is } 180-270 \text { days. One or two dry months. } \\
\text { Annual mean temperature, } 15^{\circ} \mathrm{C}-18^{\circ} \mathrm{C} \text {, Monthly minimum } 8^{\circ} \mathrm{C}-11^{\circ} \mathrm{C} \text {, no frost }\end{array}$ \\
\hline LH3 & 5 & $\begin{array}{l}\text { Semi-humid, Lower Highland. Three to five dry months, Annual mean temperature, } 15^{\circ} \mathrm{C}-18^{\circ} \mathrm{C} \text {, } \\
\text { Monthly minimum } 8^{\circ} \mathrm{C}-11^{\circ} \mathrm{C} \text {, no frost }\end{array}$ \\
\hline LH4 & 5 & $\begin{array}{l}\text { Transitional, Lower Highland with two dry seasons. Annual mean temperature, } 15^{\circ} \mathrm{C}-18^{\circ} \mathrm{C} \text {, Monthly } \\
\text { minimum } 8^{\circ} \mathrm{C}-11^{\circ} \mathrm{C} \text {, no frost }\end{array}$ \\
\hline UH2 & 10 & $\begin{array}{l}\text { Sub-humid, Upper Highland. Length of growing period is } 180 \text { - } 270 \text { days. One or two dry months., } \\
\text { Annual mean temperature, } 10^{\circ} \mathrm{C}-15^{\circ} \mathrm{C} \text {, occasional night frost }\end{array}$ \\
\hline UH1 & 18 & $\begin{array}{l}\text { Humid, Upper Highland. Length of growing period greater than } 270 \text { days. Evergreen. Annual mean } \\
\text { temperature, } 10^{\circ} \mathrm{C}-15^{\circ} \mathrm{C} \text {, occasional night frost }\end{array}$ \\
\hline UHO & 6 & Per humid, Upper Highland. Ever wet, Annual mean temperature, $10^{\circ} \mathrm{C}-15^{\circ} \mathrm{C}$, occasional night frost \\
\hline
\end{tabular}

was used to show specific AEZs with significant differences in basal areas.

\section{Results}

\subsection{Species Dominance among AEZ}

Tabernaemontana stapfiana (Britten) had the highest relative dominance among AEZ. The tree was best ranked in Lower Highland 1 (LH1), Upper Highland 1 (UH1) and Upper Highland 0 (UH0) with relative dominance values of $22.66 \%, 22.89 \%$ and $30.73 \%$ respectively (Table 2). The species was however not recorded in any of the other AEZs. Dominant trees in other lower highland zones; LH2, LH3 and LH4 were J. procera (15.78\%), Ficus exasperata Vahl (24.56\%) and A. schimperi (31\%) respectively. In the highland zone 2 (UH2), O. europaea ssp. africana with a relative dominance of $12.19 \%$ was best ranked.

Other highly ranked species (Table 2) included Allophylus abyssinicus (Hochst. Radlk) in LH1 (10.92\%), D. goetzenii in LH2 (11.03\%), Celtis africana (Burm.f.) in LH3 (22.07\%) and Cussonia spicata (Thunb.) in LH4 (22.12\%). In the upper highland zones, Ficus thonningii (Blume) (18.08\%), Syzygium guineense (Willd. DC.) (10.38\%) and Euphorbia candelabrum (Kotschy) (10.60\%) were ranked second in the UH0, UH1 and UH2 AEZ, respectively.

There was no single species recorded in all the 7 AEZs an indication that no species withstands the variety of ecological conditions of the whole Mau Forest Complex. However, D. goetzenii had the highest relative frequency (Magurran, 1988) occurring in 6 of the 7 AEZ. Other species occurring in 5 of the 7 AEZ were A. abyssinicus, Casearia battiscombei (R.E.Fr.), Cassipourea malosana (Baker Alston), Ficus thonningii (Blume) and Olea capensis (L.). There were a number of species occurring in 4 AEZs including C. macrostachyus, D. afromontana, Ilex mitis (L. Radlk.), Macaranga capensis (Baill. Sim), Polyscias fulva (hiern harms) and Prunus africana (Hook.f. Kalkman).

Species richness by simple counting [27] showed that the Upper Highland 1 (UH1) was richest with 36 tree species. The Lower highland zones indicated a decreasing richness from the wetter zones towards the drier ones. There were 31 tree species in LH1, 27 species in LH2 and 14 species in LH3.

The dominance of the species was very typical of the ecological conditions of their growth [12] and [17] with more species in the wetter areas. However, the dominance of $T$. stapfiana may be due to its lack of economic value and degradation that targets commercial trees has no effect on it. Reference [13] identified T. stapfiana as fire tolerant, surviving in fire prone areas where other species are easily eliminated. In the Lower Highland 3 (LH3), the dominance of Ficus exasperata was because the other species recorded here do not grow into big sizes and a single tree of this species may have contributed greatly to the basal area averages. Juniperus procera though targeted for poles and posts in this forest [13] has quick regeneration capacity which favours its survival [29].

The results of species dominance would enhance the classification of the forest into species associations and 
Table 2. Ranking of species by relative dominance (\% contribution to plot basal area) in the 7 AEZ.

\begin{tabular}{cccccccccccccc}
\hline LH1 & $\%$ & LH2 & $\%$ & LH3 & $\%$ & LH4 & $\%$ & UH0 & $\%$ & UH1 & $\%$ & UH2 & $\%$ \\
\hline T. stapfiana & 22.6 & J. procera & 15.8 & F. exasperata & 24.6 & A. schimperi & 31.0 & T. stapfiana & 30.7 & T. stapfiana & 22.9 & O. africana & 12.2 \\
A. abyssinicus & 10.9 & D. goetzenii & 11.0 & C. africana & 22.1 & C. spicata & 22.1 & F. thonningii & 18.1 & S. guineense & 10.4 & E. candelabrum 10.6 \\
E. capensis & 10.6 & C. battiscombei & 9.7 & C. holstii & 15.6 & O. europeae & 16.8 & O. capensis & 16.1 & P. latifolius & 8.2 & S. guineense & 8.7 \\
A. gummifera & 8.1 & P. africana & 9.4 & T. nobilis & 8.7 & T. nobilis & 8.3 & N. macrocalyx & 14.3 N. macrocalyx & 7.1 & P. fulva & 8.1 \\
N. macrocalyx & 7.3 & E. buchananii & 8.6 & D. goetzenii & 7.4 & E. divinorum & 4.7 & C. malosana & 5.6 & F. thonningii & 6.2 & M. undatus & 7.2 \\
C. malosana & 6.5 & A. abyssinicus & 8.4 & E. cymosa & 6.0 & A. lahai & 2.9 & A. abyssinicus & 5.0 & S. volkensii & 5.7 & A. gummifera & 7.1 \\
C. battiscombei & 5.5 & P. latifolius & 7.1 & T. ellipticus & 5.3 & C. holstii & 2.3 & G. coffeoides & 2.3 & E. capensis & 4.6 & P. africana & 6.3 \\
P. africana & 3.0 & O. capensis & 6.4 & F. populifolia & 4.3 & E. abyssinica & 2.3 & D. afromontana & 2.1 & O. capensis & 4.4 & F. natalensis & 6.2 \\
P. fulva & 2.4 & P. fulva & 4.4 & A. abyssinicus & 2.2 & F. usambarensis & 2.3 & C. battiscombei & 1.5 & E. buchananii & 3.9 & O. rochetiana & 5.7 \\
O. rochetiana & 2.3 & T. nobilis & 4.2 & V. infausta & 1.8 & I. mitis & 1.8 & M. capensis & 0.9 & P. africana & 3.5 & O. capensis & 5.6 \\
\hline
\end{tabular}

forest types in various AEZ. The LH1, has Tabernaemontana-Allophylus-Ekebergia-Albizia species association while the LH2 has a Juniperus-Dombeya-Casearia-Prunus species association. In the LH4 the AcokantheraCussonia-Olea-Teclea species association dominates while in the UH1 Tabernaemontana-Syzygium-Podocarpus-Neoboutonia species association exists.

Tree species with big sized individuals and also occurring in a variety of ecological conditions are ideal for the rehabilitation of the degraded Mau forest [14] and [15]. Since the government has initiated efforts for the rehabilitation of the Mau forest as a water tower and an important biodiversity hotspot, it is necessary that ideal tree species that can survive well in the variety of ecological conditions be selected.

\subsection{Species Dominance in the MFC}

Due to its high ranking in LH1, UH1 and UH0, T. stapfiana was the highest ranked species in the study area. The species had a relative dominance of $14.27 \%$ with an average basal area of $2.74 \mathrm{~m}^{2} \cdot \mathrm{ha}^{-1}$. Co-dominant species included $O$. capensis (relative dominance of $5.74 \%$ and basal area of $1.10 \mathrm{~m}^{2} \cdot \mathrm{ha}^{-1}$ ), F. thonningii (relative dominance of $5.62 \%$ and basal area of $1.08 \mathrm{~m}^{2} \cdot \mathrm{ha}^{-1}$ ), N. macrocalyx (relative dominance of $5.51 \%$ and basal area of $1.06 \mathrm{~m}^{2} \cdot \mathrm{ha}^{-1}$ ), A. abyssinicus (relative dominance of $4.79 \%$ and basal area of $0.92 \mathrm{~m}^{2} \cdot \mathrm{ha}^{-1}$ ), $P$. africana (relative dominance of $3.54 \%$ and basal area of $0.68 \mathrm{~m}^{2} \cdot \mathrm{ha}^{-1}$ ) and $C$. battiscombei (relative dominance of $3.43 \%$ and basal area of $0.66 \mathrm{~m}^{2} \cdot \mathrm{ha}^{-1}$ ). There was no significant difference in basal area for the best ranked 10 species $\left(\chi_{0.05,9}^{2}=3.76,0.75<\mathrm{P}<0.5\right)$ indicating that no species can be described as mono dominant in the Mau Forest Complex.

Since $T$. stapfiana has a $14 \%$ contribution to the forest basal area, its specific wood density factor would influence the overall biomass of the MFC. Reference [25] have cited examples of Schinziophyton rautanenii (Schinz Radcl.-Sm.) which has a wood density of $0.15 \mathrm{gcm}^{-3}$ and Dalbergia melanoxylon with a wood density of $1.2 \mathrm{gcm}^{-3}$ and explained that it would be erroneous to use the same factor to convert basal area to wood biomass for the two species and similarly using one allometric equation for carbon mapping for the two species would be erroneous. Reference [24] did species weighting by relative dominance to reduce such bias.

The fact that $T$. stapfiana and D. goetzenii that were dominant in the study area, also grow in the other montane forests of Kenya, which comprise the major forested regions of the country, it should be prioritised for further analysis including dominance and development of species specific allometric equations.

\subsection{Species Similarity Indices}

Similarity of occurrence among AEZ (Table 3) indicated that species of Upper Highland 1 (UH1) harmonised best in the other AEZ. The UH1 had a species similarity of 67\% with LH1, 63\% with LH2 and 56\% with LH4. However species in the very humid zone UH0 differed with those of the drier lower highland zones. The UH0 had a species similarity of only $31 \%$ and $37 \%$ with LH3 and LH4, respectively. 
Table 3. Percentages of species similarities of occurrence between AEZs.

\begin{tabular}{cccccccc}
\hline & LH1 & LH2 & LH3 & LH4 & UH0 & UH1 & UH2 \\
\hline LH1 & 100 & 58.4 & 45.3 & 51.4 & 48.2 & 67.7 & 53.4 \\
LH2 & & 100 & 41.1 & 47.0 & 44.1 & 63.5 & 49.4 \\
LH3 & & 100 & 34.1 & 31.1 & 50.1 & 36.1 \\
LH4 & & & 100 & 37.0 & 56.1 & 42.2 \\
UH0 & & & & 100 & 53.5 & 39.3 \\
UH1 & & & & & & & 58.9 \\
UH2 & & & & & & & \\
\hline
\end{tabular}

The findings on species similarity which show that species composition varies with ecological conditions, is important in the sustainable utilisation and conservation of the MFC. Reference [15] explained that specific species in the MFC are over exploited by the various disturbance factors and some do not regenerate easily. Similarly the findings indicate the kind of species that should be planted at the various ecological zones.

\subsection{Basal Area among the AEZ}

The average basal area for the study area was $19.21 \mathrm{~m}^{2} \cdot \mathrm{ha}^{-1}$ which compares well with the $17.4 \mathrm{~m}^{2} \cdot \mathrm{ha}^{-1}$ [30] for the whole MFC. The basal areas for the AEZs was lowest in LH4 $\left(7.68 \mathrm{~m}^{2} \cdot \mathrm{ha}^{-1}\right.$ ) and highest in UH0 (29.10 $\mathrm{m}^{2} \cdot \mathrm{ha}^{-1}$ ). Between the two ranges, the LH1 and LH2 had $22.45 \mathrm{~m}^{2} \cdot \mathrm{ha}^{-1}$ and $23.74 \mathrm{~m}^{2} \cdot \mathrm{ha}^{-1}$ respectively while LH3 had $11.6 \mathrm{~m}^{2} \cdot \mathrm{ha}^{-1}$. The distribution of basal areas among AEZ was significantly different $(\mathrm{P}<0.01)$. Tukey's multiple comparison test showed no difference between UH0, LH1, LH2 and UH1 on the higher level of stocking. Similarly on the lower level of stocking, UH2, LH3 and LH4 did not differ. The difference in ANOVA is therefore associated with the variation in regions of higher stocking and those of poor stocking. While upper highland zones of UH0 and UH1 and also the Lower highland Zone of LH1 which had good stocking have higher rainfall and therefore more favourable growing conditions, the low stocking in the Upper Highland zone of UH2 can only be attributed to human degradation.

The basal area findings would agree with agricultural productivity estimates where regions with more moisture content have higher productivity. This is depicted in UH0, LH1 and UH1 for good stocking. Similarly, the transitional zone (LH4) with low moisture had poor stocking which may be associated to climatic factors. However, UH2 deviates from the expected trend. This is in the upper highland and the moisture conditions are good. It was expected to have higher values of basal area. The ground data collection confirmed that the area depicted clear evidence of disturbance by fires and the vegetation was on the recovery trend.

The differences in basal area stocking among the AEZ explain the potential productivity of the various regions of the MFC. While there are highly productive areas where huge tress stock a lot of biomass, there are also fragile areas where disturbance activities would clear the little vegetation present leaving the forest bare.

\section{Conclusions}

This study provides information on the tree species of the MFC, their distribution and sizes among AEZs. This information is relevant to conservation activities in the MFC whose rehabilitation is a priority of the Kenyan government. The information also supports biomass mapping which is a requirement in the on-going national forest inventories for purposes of greenhouse gas inventory. The basal area values may illustrate the existence of biomass corridors that follow the AEZ boundaries.

The findings have illustrated that the dominance of species varies among agro ecological regions of the Mau Forest Complex. It was only T. stapfiana that showed dominance in three AEZs while D. goetzenii was the most adaptable species occurring in most sites. This finding supports theories of co-dominance which makes the vegetation of the MFC rich in biodiversity and forest roles. The different species have their specific role in supporting the biodiversity chains. Therefore the variation in species characteristics of the MFC illustrates the unique habitats that exist in the different regions. Similarly, the fact that only a few trees would adapt to the va- 
riety of ecological conditions of the MFC, rehabilitation programmes that aim at tree planting should identify the most appropriate species for each area.

The findings reflect the species characteristics for only trees sizes bigger than $10 \mathrm{~cm}$ Dbh. It should be noted that the species richness of the MFC is beyond this diameter size class and inclusion of lower sized trees may have influenced other aspects of species dominance. However, since the MFC is the largest block of montane forests in Kenya, the findings may reflect the characteristics of species composition in the other similar forests.

\section{Acknowledgements}

Data for this project was obtained from two sources; a Ph.D programme titled Effect of human encroachment on forest cover, structure and composition in the western blocks of the MFC and a NACOSTI funded project titled the role of the MFC as a carbon sink. We thank NACOSTI and AFORNET for the funding, and the Department of Resource Surveys and Remote Sensing for facilitating data collection.

\section{References}

[1] Lohbeck, M., Poorter, L., Martínez-Ramos, M., Rodriguez-Velázquez, J., van Breugel, M. and Bongers, F. (2014) Changing Drivers of Species Dominance during Tropical Forest Succession. Functional Ecology, 28, 1052-1058. http://dx.doi.org/10.1111/1365-2435.12240

[2] Priya, D., Jean, P.P. and Egbert, G.L. (2005) Changes in Rain Forest Tree Diversity, Dominance and Rarity across a Seasonality Gradient in the Western Ghats. Indian Journal of Biogeography, 32, 493-501. http://dx.doi.org/10.1111/j.1365-2699.2005.01165.x

[3] Chase, J.M. and Leibold, M.A. (2003) Ecological Niches: Linking Classical and Contemporary Approaches. University of Chicago Press, Chicago. http://dx.doi.org/10.7208/chicago/9780226101811.001.0001

[4] Burak, K.P., Roy, S.W., Matthias, M.B., Craig, M. and Pauline, F.G. (2011) Response of Plant Species and Life Form Diversity to Variable Fire Histories and Biomass in the Jarrah Forest of South-West Australia. Austral Ecology, 37, 330-338.

[5] Magurran, A.E. (1988) Ecological Diversity and Its Measurement. Chapman and Hall, London. http://dx.doi.org/10.1007/978-94-015-7358-0

[6] Tania, U.H., Paul, M.D. and Carlos, A.P. (2007) Regional Scale Variation in Forest Structure and Biomass in the Yucatan Peninsula, Mexico: Effects of Forest Disturbance. Forest Ecology and Management, 247, 80-90. http://dx.doi.org/10.1016/j.foreco.2007.04.015

[7] Bohlman, S. and Pacala, S. (2012) A Forest Structure Model that Determines Crown Layers and Partitions Growth and Mortality Rates for Landscape-Scale Applications of Tropical Forests. Journal of Ecology, 100, 508-518. http://dx.doi.org/10.1111/j.1365-2745.2011.01935.x

[8] Philip, M.S. (1994) Measuring Trees and Forests. 2nd Edition, Aberdeen University Press, Aberdeen.

[9] Leigh, D., Puyravaud, D., Terborgh, S. and Wright, S.J., et al. (2004) Why Do Some Tropical Forests Have So Many Species of Trees? Biotropica, 36, 447-473.

[10] Nigel, C.A. Pitman, J.W.T., Miles, R.S., Percy, N.V., David, A.N., Carlos, E.C., Walter, A.P. and Milton, A. (2001) Dominance and Distribution of Tree Species in Upper Amazonian Terra Firme Forests. Ecology, 82, 2101-2117. http://dx.doi.org/10.1890/0012-9658(2001)082[2101:DADOTS]2.0.CO;2

[11] Schroeder, T.A., Hamann, A., Wang, T.L. and Coops, N.C. (2010) Occurrence and Dominance of Six Pacific Northwest Conifer Species. Journal of Vegetation Science, 21, 586-596. http://dx.doi.org/10.1111/j.1654-1103.2009.01163.x

[12] Beentje, H.J. (1994) Kenya Trees, Shrubs and Lianas. National Museums of Kenya, Nairobi.

[13] Kinyanjui, J.M. (2009) The Effect of Human Encroachment on Forest Cover, Structure and Composition in the Western Blocks of the Mau Forest Complex. PhD Thesis, Egerton University, Njoro.

[14] Kinyanjui, J.M. (2011) NDVI Based Vegetation Monitoring in the Mau Forest Complex, Kenya. African Journal of Ecology, 49, 165-174. http://dx.doi.org/10.1111/j.1365-2028.2010.01251.x

[15] Kinyanjui, J.M., Karachi, M. and Nyabuti, K.N. (2013) Natural Regeneration and Ecological Recovery in Mau Forest Complex, Kenya. Open Journal of Ecology, 3, 417-422. http://dx.doi.org/10.4236/oje.2013.36047

[16] Kinyanjui, M.J., Latva-Käyrä, P., Bhuwneshwar, P.S., Kariuki, P., Gichu, A. and Wamichwe, K. (2014) An Inventory of the Above Ground Biomass in the Mau Forest Ecosystem, Kenya. Open Journal of Ecology, 4, 619-627. http://dx.doi.org/10.4236/oje.2014.410052 
[17] Prance, G.T. (1984) The Vegetation of Africa. By F. White. Brittonia, 36, 273. http://dx.doi.org/10.2307/2806524

[18] Mutangah, J.G., Mwangangi, O.M. and Mwaura, P.K. (1993) Mau Forest Complex Vegetation Survey. KIFCON Report, Nairobi.

[19] Fischer, G., Velthuizen, H., Shah, M. and Nachtergaele, F. (2002) Global Agro-Ecological Assessment for Agriculture in the 21st Century: Methodology and Results. International Institute for Applied Systems Analysis, Laxenburg.

[20] Quiroz, R., Zorogastúa, P., Baigorria, G., Barreda, C., Valdivia, R., Cruz, M. and Reinoso, J. (2000) Toward a Dynamic Definition of Agroecological Zones Using Modern Information Technology Tools. CIP Program Report 19992000.

[21] Sombroek, W.G., Braun, H.M.H. and van der Pouw, B.J.A. (1982) Exploratory Soil Map and Agro-Climatic Zone Map of Kenya, 1980. Scale: 1:1,000,000. Exploratory Soil Survey Report No. E1. Kenya Soil Survey Ministry of Agriculture, National Agricultural Laboratories, Nairobi.

[22] Sehgal, J., Mandal, D.K., Mandal, C. and Vadivelu, S. (1992) Agro-Ecological Regions of India. 2nd Edition, Technical Bulletin No. 24, NBSS and LUP, $130 \mathrm{p}$.

[23] Coops, N.C., Gaulton, R. and Waring, R.H. (2011) Mapping Site Indices for Five Pacific Northwest Conifers Using a Physiologically Based Model. Applied Vegetation Science, 14, 268-276. http://dx.doi.org/10.1111/j.1654-109X.2010.01109.x

[24] Kinyanjui, J.M., Karachi, M. and Ondimu, K.N. (2012) Documenting the Carbon Content of the Mau Forest Complex. Journal of Environment, Natural Resources Management and Society, 1, 70-81.

[25] Henry, M., Picard, N., Trotta, C., Manlay, R.J., Valentini, R., Bernoux, M. and Saint-André, L. (2011) Estimating Tree Biomass of Sub-Saharan African Forests: A Review of Available Allometric Equations. Silva Fennica, 45, 477-569. http://dx.doi.org/10.14214/sf.38

[26] Jaetzold, R., Schmidt, H., Hornet, Z.B. and Shisanya, C.A. (2007) Farm Management Handbook of Kenya. Natural Conditions and Farm Information. 2nd Edition, Vol. 11/C. Central Province, Ministry of Agriculture/GTZ, Nairobi.

[27] Kent, M. and Coker, P. (1992) Vegetation Description and Analysis. John Wiley and Sons, New York.

[28] Zar, J.H. (2010) Biostatistical Analysis. 5th Edition, Prentice-Hall, Englewood Cliffs, NJ, 944.

[29] Borghesio, L., Giannetti, F., Ndang'ang’a, K. and Shimelis, A. (2004) The Present Conservation Status of Juniperus Forests in the South Ethiopian Endemic Bird Area. African Journal of Ecology, 42, 137-143. http://dx.doi.org/10.1111/j.1365-2028.2004.00511.x

[30] Blackett, H.L. (1994) Forest Inventory Reports for Kenya’s Indigenous Forests. KIFCON Report, Nairobi. 
Scientific Research Publishing (SCIRP) is one of the largest Open Access journal publishers. It is currently publishing more than 200 open access, online, peer-reviewed journals covering a wide range of academic disciplines. SCIRP serves the worldwide academic communities and contributes to the progress and application of science with its publication.

Other selected journals from SCIRP are listed as below. Submit your manuscript to us via either submit@scirp.org or Online Submission Portal.
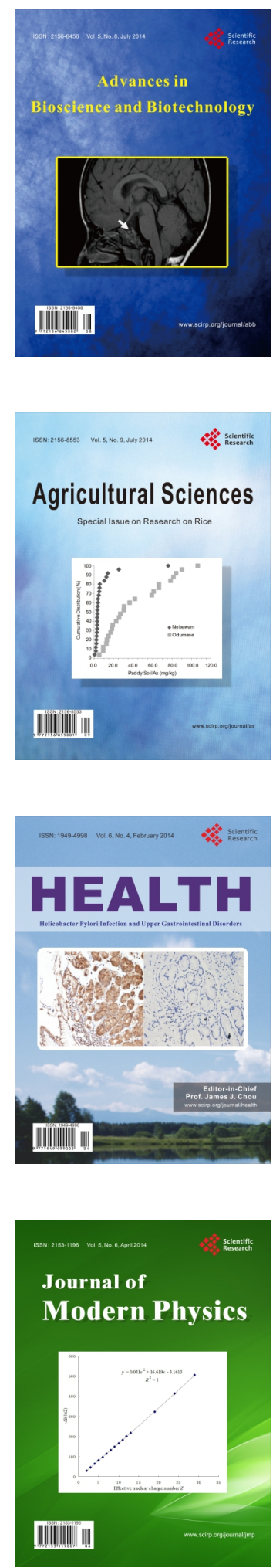
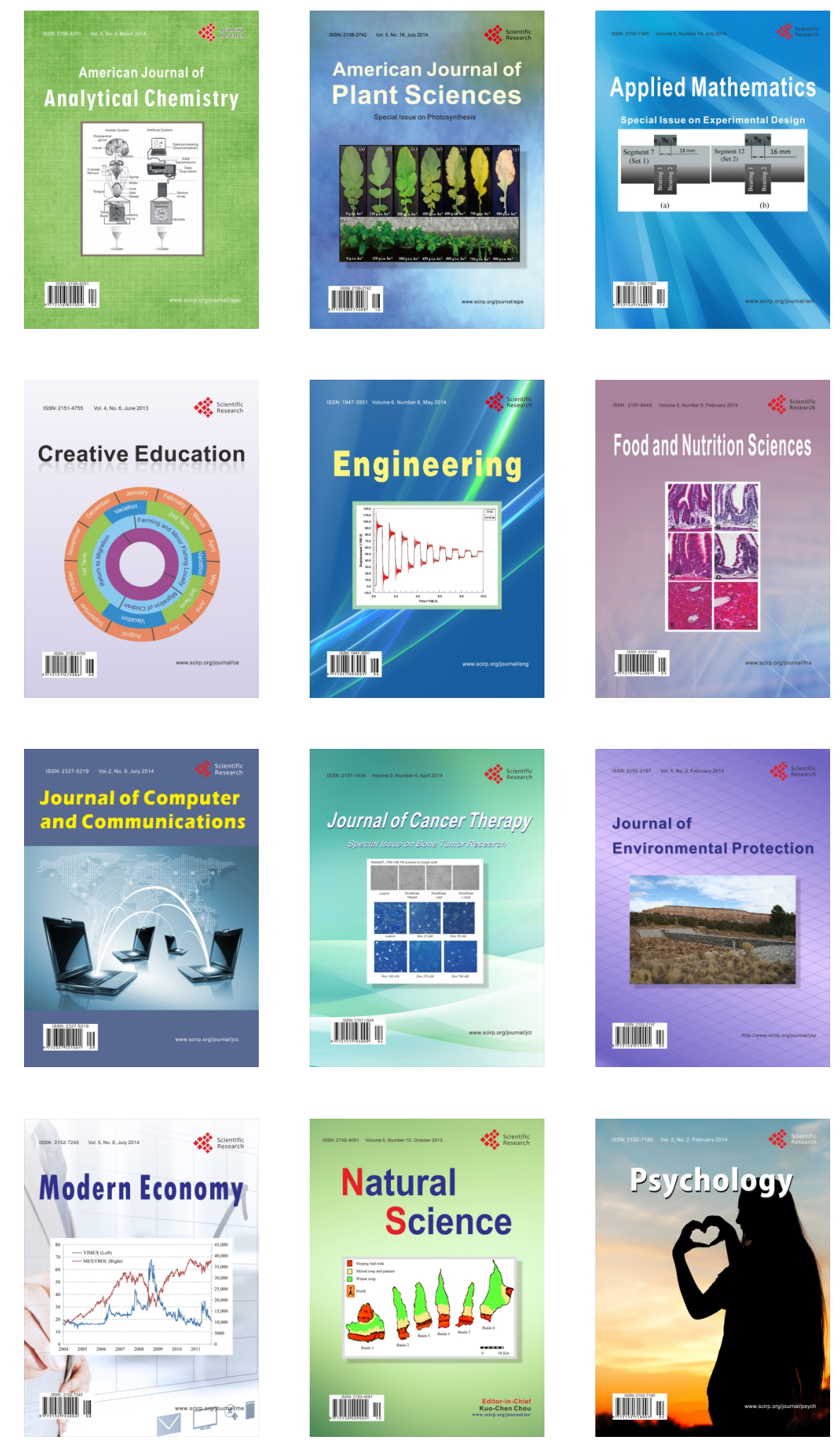